\title{
COLLATERAL ATTACK FOR LACK OF SUBJECT MATTER JURISDICTION
}

The Durfees, residents of Nebraska, brought an action to quiet title to bottom land situated on the Missouri River at a point where the river forms the boundary between Nebraska and Missouri. The Nebraska court had jurisdiction over the subject matter of the controversy only if the land was in Nebraska. Whether the land was in Nebraska depended upon a factual question-whether a shift in the river's course had been caused by avulsion or by accretion. Juha Duke, who claimed the land under a Missouri land patent, appeared in the Nebraska court and fully hitigated all issues, specifically challenging its jurisdiction over the subject matter on the ground that the land was in Missouri. After a factual determination that the land remained in Nebraska, the court quieted title in the Durfees. Duke appealed, and the Supreme Court of Nebraska affirmed the judgment after a trial de novo on the record made in the lower court. ${ }^{1}$ No review was sought before the United States Supreme Court.

Two months later Duke filed a suit in a Missouri state court to quiet title to the same land. The Durfees removed the suit to a federal district court in Missouri, which dismissed the action on the ground that since the issues had been adjudicated in the Nebraska hitigation, the Nebraska judgment was res judicata. The court of appeals reversed, ${ }^{2}$ holding that the policy against a court exercising jurisdiction over land beyond its boundaries is so strong that the normal rules of res judicata do not apply. Thus the Missouri court was free to retry the question of the Nebraska court's jurisdiction over the subject matter. The case was taken to the United States Supreme Court which reversed, ${ }^{3}$ holding that the Nebraska judgment must be accorded full-faith-and-credit. Although courts of one state do not have jurisdiction to directly affect title to land in other states, ${ }^{4}$ the location of land is a factual question to be resolved by judicial determination. Such a determination is entitled to full-faithand-credit, even when it decides jurisdictional questions, if the second court's inquiry discloses that those questions have been "fully and fairly hitigated and finally decided in the court which rendered the original judgment."

Despite its unique factual setting, the holding of Durfee v. Duke fits solidly within the framework created by preceding cases. In its re-

\footnotetext{
1 Durfee v. Keiffer, 168 Neb. 272, 95 N.W.2d 618 (1959).

2 Duke v. Durfee, 308 F.2d 209 (8th Cir. 1962).

3 Durfee v. Duke, 375 U.S. 106 (1963).

1 Fall v. Eastin, 215 U.S. 1 (1909).

5375 U.S. at 111.
} 
consideration of collateral attack for lack of subject matter jurisdiction, however, the Court used language which may indicate a change in its attitude. The purpose of this Comment is threefold: (1) to examine the cases preceding Durfee v. Duke to determine what rule the Supreme Court has developed as a compromise between the conflicting policies underlying res judicata and collateral attack; (2) to explore the possibility that Durfee augurs a more lement attitude towards collateral attack where the issue of jurisdiction has not been litigated; and (3) to discuss certain language in the majority and concurring opinions in relation to bigamy prosecutions in which one state collaterally attacks the validity of a divorce decree rendered by another.

THE LIMITATIONS ON COLLATERAI ATTACK

The constitutional command of full-faith-and-credit, ${ }^{\beta}$ as implemented by Congress, ${ }^{7}$ requires that "judicial proceedings . . . shall have the same full-faith-and-credit in every court within the United States ... as they have by law or usage in the courts of such state ... from which they are taken." Accordingly, it has been held that state courts must recognize and enforce the judicial proceedings not only of other states, ${ }^{8}$ but also those of the federal courts. ${ }^{9}$ Likewise, federal courts are bound to respect state judicial determinations. ${ }^{10}$

A frequently stated exception is that a judgment rendered by a court without jurisdiction is absolutely void and may be collaterally attacked in another forum. ${ }^{11}$ Since such a judgment is said to deny due process to the parties and is unenforceable anywhere, ${ }^{12}$ this principle is not really

6 U.S. Const. art. IV, $\S 1$.

728 U.S.C. \& 1738 (1958).

8 E.g., Sistare v. Sistare, 218 U.S. 1 (1910).

9 E.g., Hancock Nat'l Bank v. Farnum, 176 U.S. 640 (1900).

10 E.g., Treinies v. Sunshine Mining Co., 308 U.S. 66 (1939); see 63 Coluar. L. REv. 353 (1963).

11 E.g., Williams v. North Carolina, 325 U.S. 226, 238 (1945) (subject matter-marital status); Clarke v. Clarke, 178 U.S. 186 (1900) (subject matter jurisdiction-land); Pennoyer v. Neff, 95 U.S. 714, 732-34 (1877) (personal jurisdiction); Thompson v. Whitman, 85 U.S. (18 Wall.) 457 (1873) (subject matter jurisdiction-personalty); D'Arcy v. Ketchum, 52 U.S. (11 How.) 165 (1850) (personal jurisdiction); RestateaMENT, JUDGMENTS $§ 5$, comment $c$ (1942); 1 FreEaran, JUDGMIENTS $\S 333$, at 669 (5th ed. 1925). This rule will be referred to hereafter as the Thompson-Whitman rule. An early and authoritative formulation of this doctrine may be found in Coorex, Constrtumonat Linatatrons, 398-99 (4th ed. 1878).

12 Restatement, Judgaments \$ 11, comment $c$ (1942); Reese \& Johnson, The Scope of Full Faith and Credit to Judgments, 49 CoLOM. L. REv. 153, 166 (1949). 
an exception to the general requirement of full-faith-and-credit. ${ }^{13}$ It does, however, pose a real problem, for if every judgment were subject to attack on jurisdictional grounds, the efficient working of the judicial machinery would be severely impaired. The Supreme Court has attempted to solve this problem by applying res judicata principles. ${ }^{14}$ It has held that the full-faith-and-credit clause "generally requires every State to give to a judgment at least the res judicata effect which the judgment would be accorded in the State which rendered it."15 Thus each case would appear to require a determination of whether a collateral attack for lack of subject matter jurisdiction ${ }^{16}$ would be allowed (1912).

${ }^{13}$ See Bigelow v. Old Dominion Copper Mining \& Smelting Co., 225 U.S. 111, 137

14 It appears that the application of res judicata in these cases is based on the same policy considerations that underlie its application in other contexts, despite the doctrinal objection to a court acting beyond its jurisdiction. This has been justified in various ways. In a state-state context the source of the application of res judicata has been the full faith and credit clause. See Sherrer v. Sherrer, 334 U.S. 343 (1948); Davis v. Davis, 305 U.S. 32 (1938) (state-District of Columbia); American Sur. Co. v. Baldwin, 287 U.S. 156 (1932). Where the case has originated in a federal court in the same state, the Supreme Court has justified the bar to collateral attack on the policy grounds underlying res judicata-that there be an end to litigation. See Chicot County Drainage Dist. v. Baxter State Bank, 308 U.S. 371 (1940); Stoll v. Gottlieb, 305 U.S. 165 (1938); Forsyth v. Hammond, 166 U.S. 506 (1897). In most of these cases collateral attack was barred without any mention of the Thompson-Whitman exception, thus avoiding rather than disposing of the major doctrinal objection to denying collateral attack. See note 11 supra and accompanying text. But see Treinies v. Sunshine Mining Co., 308 U.S. 66 (1939) (state-state context), where the Court, while approving the Thompson-Whitman proposition that the power of forum II to examine the jurisdiction of forum I is "beyond question," barred collateral attack when a Washington court challenged an Idaho court's determination that the Washington court did not have jurisdiction in a prior action. There are two possible explanations for the Court's refusal to require Idaho to give full faith and credit to the original Washington judgment: (1) the Court emphasized that the Idaho court was a court of general jurisdiction, implying that a judgment rendered by a court of limited jurisdiction (the Washington court) may always be collaterally attacked; (2) the Idaho judgment could have been attacked directly for failure to grant full faitl and credit to the Washington determination. Having failed to do so the parties were barred from collaterally attacking it in a subsequent action. Regardless of which explanation was the basis of the Court's holding, it appears that its affirmance of the Thompson-Whitman rule is illusory.

16375 U.S. at 109. See Riley v. New York Trust Co., 315 U.S. 343, 349 (1942); American Sur. Co. v. Baldwin, 287 U.S. 156, 166-67 (1932).

16 This Comment is limited to a consideration of collateral attack for lack of subject matter jurisdiction. With respect to questions of personal jurisdiction, it was decided in American Sur. Co. v. Baldwin, 287 U.S. 156 (1932), and Baldwin v. Iowa State Traveling Men's Ass'n, 283 U.S. 522 (1931), that this determination would be conclusive, so long as due process is afforded the contesting party. See Restatenent, Judgarents $\$ 9$ (1942). The requirements of due process are discussed in Adam v. Saenger, 303 U.S. 59 (1938); Pennoyer v. Neff, 95 U.S. 714 (1877); and York v. Texas, 137 U.S. 15 (1890). The application of this principle in each case provides a satisfactory solution to the problem of collateral attack for lack of personal jurisdiction, since the strong state and federal policies that complicate the problem with regard to subject matter jurisdiction are absent. 
in the state which rendered the original judgment. ${ }^{17}$ The availability of collateral attack would accordingly depend on the res judicata rule of each state.

The Supreme Court, however, has not considered the state res judicata rule decisive. Once it finds that the original forum would bar collateral attack, it applies a test of its own which balances the type of jurisdictional issues involved against the extent to which these issues were litigated. ${ }^{18}$ The strength which each of these factors is to be given, however, is unclear. ${ }^{19}$ In all cases in which the jurisdictional question was raised and fully litigated in the original forum, the decision has been held to be res judicata in a subsequent action between the parties. ${ }^{20}$ Moreover, where the question of subject matter jurisdiction was not fully hitigated, the general rule appears to be that the original decision will be res judicata in a subsequent action if the issue could have been litigated. ${ }^{21}$

\footnotetext{
17 See, e.g., 375 U.S. at 109 n.6.

18 See 375 U.S. at 111 ; Sherrer v. Sherrer, 334 U.S. 343, 351 (1948).

19 The Restatement of Judgments has formulated a balancing test to determine whether collateral attack will be allowed: "Where a court has jurisdiction over the parties and determines that it has jurisdiction over the subject matter, the parties cannot collaterally attack the judgment on the ground that the court did not have jurisdiction over the subject matter, unless the policy underlying the doctrine of res judicata is outweighed by the policy against permitting the court to act beyond its jurisdiction. ... Among the factors appropriate to be considered in determining that collateral attack should be permitted are that: (a) the lack of jurisdiction over the subject matter was clear; (b) the determination as to jurisdiction depended upon a question of law rather than a fact; (c) the court was one of limited and not of general jurisdiction; (d) the question of jurisdiction was not actually litigated; (e) the policy against the court's acting beyond its jurisdiction is strong." RESTATEMENT, JUDGMENTS \& 10 (1942).

20 Durfee v. Duke, 375 U.S. 106 (1963). In Treinies v. Sunshine Mining Co., 308 U.S. 66 (1939), the Idalo court's adjudication that a Washington probate court's judgment was void for lack of jurisdiction was given full faith and credit in a subsequent Washington action although the jurisdictional question had been litigated in the previous Washington action. The Court held that the Idaho judgment could only be attacked indirectly. Sce discussion note 14 supra. In Stoll v. Gottheb, 305 U.S. 165 (1938), a bankruptcy court's adjudication, on a bondholder's motion to vacate, that it had jurisdiction to cancel the guaranty of the debtor's bonds was held to preclude subsequent action on the guaranty in the state court. Davis v. Davis, 305 U.S. 32 (1938), involved an adjudication in a Virginia divorce action that, despite the wife's bona fide contest of the issue, the husband had acquired a Virginia domicile. The determination was held to be entitled to full-faith-andcredit in the District of Columbia.

21 In Sherrer v. Sherrer, 334 U.S. 343 (1948), a Florida divorce decree was held to be entitled to full-faith-and-credit where husband appcared in Florida proceeding but failed to contest the wife's allegations of domicile. In Chicot County Drainage Dist. v. Baxter State Bank, 308 U.S. 371 (1940), following a decree in a federal district court approving a plan of readjustunent under a federal act, the act was found to be unconstitutional in an action involving different parties. A subsequent action by a losing party in the original action was barred on res judicata grounds. The characterization of Sherrer as a case where the question of subject matter jurisdiction was not fully litigated is disputable. See text
} 
There are two cases in which the Court has allowed the parties to challenge jurisdiction in a collateral action. In Kalb v. Feuerstein ${ }^{22}$ and United States v. United States Fidelity \& Guar. $\mathrm{Co}^{23}$ the Supreme Court allowed collateral attack on the grounds that the policy underlying res judicata, ${ }^{24}$ that there should be an end to litigation, was outweighed by a strong federal policy that would be obstructed if the court were allowed to act in excess of its jurisdiction. It is difficult, however, to draw from these cases principles that will enable one to state with any precision the situations in which policy considerations will outweigh the doctrine of res judicata. ${ }^{25}$

Since in neither Kalb nor Fidelity was the question of jurisdiction actually raised in the original forum, one might suspect that collateral attack will be allowed only in such circumstances. This suspicion is supported by the absence of any case in which collateral attack was allowed after full litigation of the jurisdictional issue. There is, however, language in $K a l b$ which indicates that collateral attack might be allowed despite

accompanying note 36 infra. But see Johnson v. Muelberger, 340 U.S. 581 (1951), where the Court recognized Sherrer as holding that full faith and credit was to be accorded an out-of-state divorce "by barring either party to that divorce who has been personally served or who has entered a personal appearance from collaterally attacking the decree." Id. at 587.

Legal writers are divided as to whether the principle adopted in Chicot is desirable. For discussions favoring this principle, see Boskey \& Braucher, Jurisdiction and Collateral Attack: October Term, 1939, 40 CotuM. L. REv. 1006 (1940); Gavit, Jurisdiction of the Subject Matter and Res Judicata, 80 U. PA. L. Rev. 386 (1932) (pre-Chicot); 53 HARv. L. REv. 652 (1940); 49 YALE L.J. 959 (1940). For discussion opposing, see 40 Cosuar. L. REv. 523 (1940) (pre-Sherrer, arguing that Chicot should not apply in the state-state context) ; 39 CoLUM. L. Rev. 274 (1939).

22308 U.S. 433 (1940). The defendant in a mortgage foreclosure proceeding in a state court filed a petition in bankruptcy in a federal court pursuant to the Federal Bankruptcy Act. His collateral attack on the jurisdiction of the state court was allowed, despite the general rule that a judgment by a court of competent jurisdiction "bears a presumption of regularity and is not thereafter subject to collateral attack." Id. at 438 . The Supreme Court held that there must be an exception to this rule where Congress has expressed a strong policy that would be thwarted by a usurpation of jurisdiction. In giving exclusive jurisdiction over bankruptcy to the federal courts and ousting the state court of jurisdiction over the foreclosure proceeding, the Bankruptcy Act reflected such a strong federal poilcy. 30 Stat, 544 (1898), 11 U.S.C. $\$ 203$ (n) \& (o) (1958).

23309 U.S. 506 (1940). The Court permitted collateral attack of a judgment on a cross-claim against the United States, on the ground that since the United States had not waived its sovereign imnunity, the court entering the judgment had no jurisdiction. The doctrine of sovereign immunity was held to outweigh the pohicy underlying res judicata. If such immunity could be waived "it would subject the Government to suit in any court in the discretion of its responsible officers. This is not permissible." Id. at 513.

24 In both cases the Court recognized its holding as an exception to the general rule that judgments are entitled to res judicata effect as to questions of subject matter jurisdiction, whether litigated or not. Thus, if only indirectly, the rule set forth in Chicot County Drainage Dist. v. Baxter State Bank, 308 U.S. 371 (1940), is approved. See Boskey \& Braucher, supra note 21, at 1010.

25 At least one authority attempts to do so. See Boskey \& Braucher, supra note 21 . 
actual litigation of the jurisdictional question if a strong federal policy were present. ${ }^{26}$

The strength of the policy favoring collateral attack will depend on the nature of the jurisdictional interests involved. The Court's emphasis on the federal interests in Kalb and Fidelity suggests that perhaps only a strong federal policy will be sufficient to outweigh the policy of res judicata. ${ }^{27}$ Where the subject matter has been one in which there is no strong federal interest and the jurisdictional question has been litigated, the Supreme Court has uniformly demed collateral attack..$^{28}$ Moreover, in Sherrer v. Sherrer, ${ }^{29}$ a divorce case in which there was no effective litigation of the jurisdictional question, the Court clearly held the federal policy underlying the full-faith-and-credit clause paramount to any state interest. ${ }^{30} \mathrm{It}$ is difficult to imagine other areas where state interests will be as strong. ${ }^{31}$

\section{II}

\section{Durfee v. Duke}

In Durfee v. Duke the Supreme Court was again faced with the conflict between the policies of res judicata and collateral attack. The general rule the Court draws from an analysis of the cases preceding Durfee is that "a judgment is entitled to full-faith-and-credit-even as to questions of jurisdiction-where the second court's inquiry discloses that those questions have been fully and fairly litigated and finally decided in the court which rendered the original judgment." ${ }^{\prime 32}$ Since it was only necessary lowever to articulate a rule broad enough to include the instant case, one can not conclude that the general rule will be stated so narrowly should a case come before the Court in which the jurisdictional

26 "Congress mamifested its intention [to protect the farmers] . . . and considerations as to whether the issue of jurisdiction was actually contested in the County Court [citing Stoll], or whether it could have been contested [citing Chicot], are not applicable where the plenary power of Congress over bankruptcy has been exercised as in this Act." 308 U.S. at 444 .

27 Not all federal policies, however, will outweigh the policy of res judicata. Sec Jackson v. Irving Trust Co., 311 U.S. 494 (1941).

28 See discussion note 20 supra.

29334 U.S. 343 (1948).

30 "If in [the application of the full-faith-and-credit clause] . . . local policy must at times be required to give way, such is part of the price of our federal system I" Id. at 355 .

31 Cf. Williams v. North Carolina, 325 U.S. 226 (1945), in which the Supreme Court allowed North Carolina to collaterally attack a Nevada divorce decree for the purpose of a bigamy prosecution. This case is different, however, in that it involves the collateral attack on an out-of-state decree hy a state which was not a party to the original action. Whether North Carolina would have been allowed to attack the Nevada decrce had the issue of jurisdiction been partially litigated, as in Sherrer, is an open question.

32375 U.S. at 111. 
issue was not fully litigated. Moreover, the precedent cited by the Court as authority for its general rule presents a problem.

As examples of cases in which the question of subject matter jurisdiction was fully litigated in the original forum, the Court cites Davis, ${ }^{33}$ Stoll, ${ }^{34}$ Treinies, ${ }^{35}$ and Sherrer.$^{36}$ Although few would dispute this characterization of the first three cases, Sherrer is another matter. In Sherrer the defendant liusband appeared in a Florida divorce action and demied the wife's allegations of domicile, but did not attempt to cross-examine lier or rebut evidence of her residence. He did contest the merits of the divorce proceedings. His collateral attack of the Florida court's jurisdiction was barred. This seems somewliat less than a full hitigation of the question of jurisdiction and is equivalent to jurisdiction by consent of the parties; one party can allege facts sufficient to give the court jurisdiction while the other remains silent. A possible explanation for the citation of Sherrer might be the Court's desire to authorize collateral attack in those cases where the question of jurisdiction was not litigated without withdrawing from the position taken in the divorce cases that any appearance in person or by counsel will bar collateral attack. This, of course, is only speculation; but if the Court intended to characterize such proceedings as a "full and fair hitigation" of the jurisdictional issue, one must conclude that mere opportunity to hitigate will constitute a full litigation.

How the Court will treat cases in which it finds the jurisdictional question not fully litigated is also left open, despite the implication in the formulation of the "general rule" that collateral attack will be barred only if the question liad been fully litigated. In a footnote it observes, somewliat cryptically, that this is "not a case in which a party, although afforded an opportunity to contest subject matter jurisdiction, did not litigate the issue," State Bank. ${ }^{38}$ Since in Chicot collateral attack was barred despite the failure to raise the question of subject matter jurisdiction, it is difficult to determine the Court's meaning. The Court may have cited Chicot merely for its factual setting, but it would probably be safest to draw no inferences. Although the Court emphasizes the full hitigation of the jurisdictional question in Durfee, it nowliere expressly withdraws from the Chicot position. The emphasis on actual litigation is understandable,

33 Davis v. Davis, 305 U.S. 32 (1938). For the facts of this case see note 20 supra.

34 Stoll v. Gottlieb, 305 U.S. 165 (1938). For the facts of this case see note 20 supra.

35 Treinies v. Sunshine Mining Co., 308 U.S. 66 (1939). For the facts of this case, see note 20 supra.

36 Sherrer v. Sherrer, 334 U.S. 343 (1948).

37375 U.S. at 108 n.4.

38308 U.S. 371 (1940). 
however, since it makes the case easier for the Court. In another footnote $^{39}$ the Court uses language which might be read as a withdrawal from Chicot. Although citing Kalb and Fidelity for the proposition that collateral attack will sometimes be permitted, the Court quahifies the force of this authority by observing that in neither of these cases was the question of jurisdiction actually litigated. It may be that the Court is suggesting that collateral attack will be allowed if the jurisdictional issue lias not been hitigated. An alternative, and perliaps more reasonable interpretation is that the Court simply intended to point out that these cases are not, strictly speaking, exceptions to its rule prohibiting collateral attack where the jurisdictional question lias been fully litigated. ${ }^{10}$ Although there may be cases in which full hitigation of the jurisdictional issue will not, by itself, prohibit collateral attack, none have come before the Court.

The importance of Durfee v. Duke is difficult to evaluate. Admittedly it does for the first time apply the rule of Davis and Stoll in a land context, but as the Court pointed out, ${ }^{41}$ there appears to be no reason why the rule applicable to other questions of subject matter jurisdiction should not apply to land. Nothing decided in litigation can bind the states with respect to any controversy between them as to their sovereignty over the land in question, ${ }^{42}$ and their interests in the private litigation appear largely imaginary.

Conjecture is impossible as to the Court's treatment of the case liad the question of jurisdiction not actually been litigated; since the jurisdictional question was decisive of the merits, the case could never have arisen. ${ }^{43}$ It does appear that where an action affecting title to land is brought in another state, the Court will continue to follow the rule of Fall v. Eastin ${ }^{44}$ - that no state has the power to directly affect title to land outside its borders. ${ }^{45}$ In Durfee the Court recognizes this principle and implies that collateral attack on such a judgment will always be

39375 U.S. at 114 n.12.

40 See discussion note 24 supra.

41375 U.S. at 115.

42 Land v. Dollar, 330 U.S. 731 (1947); United States v. Lee, 106 U.S. 196 (1882).

43 Durfee's title was based on a Nebraska tax deed; Duke's clain was based on a Missouri land patent. Since the land was originally in Nebraska, the court's finding that the Iand remaimed in Nebraska automatically determined that the Durfees were the rightful owners. Missouri, never having had dominion over the land, could not bave conveyed any interest to Duke.

44215 U.S. 1 (1909).

45 Opposition to this rule is nearly unanimous. See Goodrice, Confuict or Laws 636 (3d ed. 1949); Stunarerg, Confuct or Laws 123 (2d ed. 1951); Currie, Full Failh and Credit to Foreign Land Decrees, 21 U. CEI. L. REv. 620 (1954); Radin, The Aulhenticaled Full Faith and Credit Clause: Its History, 39 IrL. L. REv. 1, 22 (1944); Schwartz, Fall v. Eastin Revisited, 54 Dick. L. Rev. 293 (1950); Note, 26 MaNN. L. REv. 264 (1942). 
allowed. With respect to other types of subject matter, however, a broad reading of the cases preceding Durfee indicates that where there has been no litigation of the jurisdictional issue, collateral attack will be barred despite Durfee's formulation of the "general rule."

It must be recognized that there is justification for more readily allowing collateral attack when the question of jurisdiction has not been litigated. The rule of Thompson v. Whitman ${ }^{46}$ authorizes a court to inquire into the jurisdiction of the rendering court before according its judgment full-faith-and-credit. Where this inquiry discloses a full litigation of the jurisdictional issue, it would be violative of the philosophy of the full-faith-and-credit clause for the inquiring court to presume that it could render a more reliable determination. On the other hand, if the jurisdictional issue was not litigated, there is less evidence that the rendering court's jurisdiction was valid. Before concluding that collateral attack should be allowed wherever the jurisdictional issue was not litigated, one should ask whether there are reasons for barring collateral attack despite the possibility that the original court acted in excess of its jurisdiction.

To answer this question requires an examination of the interests of the parties and of the state in liaving the controversy decided by the appropriate court. The only interest the parties would seem to have in an action is that the merits of their case be decided under applicable law by a fair and impartial tribunal. ${ }^{47}$ Because it must be assumed that the courts of each state are equally fair-the assumption of the fullfaith-and-credit clause-the parties seem to have no interests that will be violated solely because an unauthorized court hears their case. The objection that their case was not decided under the appropriate law is more troublesome. It can be disposed of only by making a value judgment in favor of the policy demanding that all issues be decided in one action, and that there be an end to hitigation. The parties have had a fair and impartial hearing with the opportunity to challenge the jurisdiction of that tribunal if they were dissatisfied. Failing to avail themselves of this opportunity, they have no grounds for claiming they were unfairly treated if in a later action they are barred from challenging that tribunal's jurisdiction. ${ }^{48}$ Collateral attack is thus barred on an estoppel theory.

The state, on the other hand, may have interests which cannot be

${ }^{46}$ See discussion note 11 supra and accompanying text.

47 For a general discussion of the interests involved, see Gavit, Jurisdiction of the Subject Matter and Res Judicata, 80 U. PA. L. Rev. 386, 387-89 (1932).

48 "It is just as important that there should be a place to end as that there should be a place to begin litigation." Stoll v. Gottlieb, 305 U.S. 165, 172 (1938). 
disposed of so easily. In a divorce action, for example, the state's interests in protecting the deserted spouse and children, and in preserving the family unit may be frustrated if a sister state takes jurisdiction and applies different law..$^{49}$ Moreover, the orderly administration of the state's judicial system may be obstructed if jurisdictional limitations are disregarded. Since the state is in no way responsible for the failure to challenge jurisdiction, its interests cannot be disposed of on an estoppel basis. What is required is a balancing of state interests against the federal policy that there be an end to litigation. In the usual civil litigation the main interest of the state is in the peaceful settlement of the controversy, ${ }^{50}$ and collateral attack by the state sliould be barred accordingly. Where the state's interests are of some magnitude, they may outweigh the federal policy, thus justifying a collateral attack where there was no litigation of jurisdictional questions in the first action. Perhaps the state's interests in some cases will be minimized by this procedure, but in the interest of ensuring the parties that there be an end to litigation, it appears to be the most desirable test.

\section{III}

\section{COLLATERAI ATTACK BY THE STATE}

\section{A. Mr. Justice Black's Concurring Opinion: A Caveat}

That Misouri and Nebraska are in no way bound by the decision in Durfee v. Duke presents the intriguing problem raised by Justice Black in his concurring opinion. He warns that Durfee does not decide the question "whether the respondent would continue to be bound by the Nebraska judgment sliould it later be authoritatively decided, either in an original proceeding between the States in this Court or by a compact between the two States under art. I, $\S 10$, that the disputed tract is in Missouri." ${ }^{\text {"51 }}$ Apparently Justice Black does not think the respondent would continue to be bound if the land were found to be in Missouri in a subsequent action between the States. But why should such a finding

49 It would seem that only where the law to he applied to a specific fact situation is different depending on which state assumes jurisdiction, will the state have a valid objection on the grounds that its interests are being impinged upon. Where the states are in agreement as to which law should be applied, one state's objections to its law being applied by another state would imply that the other's proceedings would be somelow prejudiced. This wonld be antithetical to the doctrine of full faith and credit which assumes that the sister state's proceedings will not be prejudiced, and which has been cluaracterized as a unifying principle for the states, not to be lightly disregarded. See Milwaukee County v. M. E. White Co., 296 U.S. 268, 277 (1935).

50 See Gavit, supra note 47 , at 388 .

51375 U.S. at 117. 
make any difference? In reviewing Durfee the Court was not concerned with whether the original determination was factually correct. Instead it emphasized the unavailed-of opportunity to appeal the Nebraska decision. In other words, the Court was willing to let the Nebraska judgment stand, correct or incorrect, rather than let the case be reopened. Consequently, a subsequent determination by the States that the land is in Missouri should have no effect on Durfee. No new state interests in support of collateral attack are created by such a decision, and the respondent's neglect to appeal the Nebraska decision is unchanged. Moreover, there remains the policy in favor of putting an end to litigation.

The situation would be similar to Chicot, where the collateral attack followed a decision in an unrelated action ${ }^{52}$ that the stâtute under which the original Chicot controversy had been decided was unconstitutional. The Court held that the collateral action was barred despite the finding of unconstitutionality. ${ }^{53}$

Although Chicot and the hypothetical situation posed by Justice Black are not identical, it appears that the principles applied in Chicot would be even more strongly applicable to a later Duke action. ${ }^{54}$ The essential similarity is that in each case substantial interests would be controlled by a lower court decision shown to be incorrect by a subsequent Supreme Court decision. This is not as undesirable as it seems. That decisions which are incorrect in an absolute sense must sometimes be treated as legally "correct" is the price we pay for having a legal system which ensures the parties that there will at some time be a defimite end to litigation. The effect on the parties if Justice Black's caveat is well-received should be considered: Durfee would improve his land with the spectre of deprivation of the land by the Court looming in the background. One must therefore conclude that Justice Black's caveat is in conflict with the principle that there should come a time when litigants can rely on a decision of their case.

\section{B. Bigamy Prosecutions and Collateral Attack}

Justice Black's concurring opinion and the language in the majority opimion to the effect that the decision in Durfee in no way controls state interests, contain principles which invite application to the perplexing problem of bigamy prosecutions. Is one state at hiberty to collaterally

62 Ashton v. Cameron County Water Improvement Dist., 298 U.S. 513 (1936).

03 Chicot County Drainage Dist. v. Baxter State Bank, 308 U.S. 371 (1940).

54 In Durfee v. Duke there was no failure to present the matter sought to be barred in the later action; the jurisdictional question had actually been raised and decided against Duke. 375 U.S. at 108. 
attack the divorce decree of a sister state in a bigamy prosecution? And assuming a successful prosecution, in which the foreign divorce was declared void on jurisdictional grounds, would the parties continue to be bound by the out-of-state decree?

It has been held that the choice of a strict or lenient divorce policy is one that must be left to the individual states. ${ }^{65}$ The right of the state to enforce its chosen policy has been limited to those persons domiciled within its borders, ${ }^{56}$ and accordingly, the Supreme Court has held that good faith domicile of at least one party is essential if a divorce decree is to be entitled to full-faith-and-credit in another state. ${ }^{57}$ Domicile, then, is the crucial concept, but a difficult one to define. ${ }^{68}$ It has been described as "a relationship between a person and a locality .... the place, and the one place, where he has his roots and his real, permanent home." But since a person can always pull up his roots and move his home to another state, it appears that the essential element in the concept of domicile is a subjective intent to treat a certain place as his permanent home. ${ }^{60}$

Thus defined, domicile can exist in only one state at a time, and if we are to avoid the anomaly of multiple domiciles, it is essential that all states employ the same definition. ${ }^{61}$ Consequently, the requirement of length of residence on which each state conditions access to its divorce courts can not, strictly speaking, be accepted as a definition of domicile. It must be recognized as an objective standard which in its strictness or leniency reflects the state's attitude towards divorce. A recital of compliance only provides a presumption of domicile satisfactory to the divorcing state; the basic requirenient is the testimony of the party that he intends to make permanent residence in that state. A collateral attack alleging lack of domicile argues that neeting the residence requirement is not sufficient evidence of domiciliary intent, and that the party perjured himself when he professed his intent to remain in the state. Thus a conflict of policies is created. In support of the attack are the interests of the state in applying its divorce policy to its domiciliaries and the due process interest in preventing courts from rendering judg-

\footnotetext{
55 Williams v. North Carolina, 317 U.S. 287, 302 (1942).

66 Id. at 303.

67 Ibid.; Bell v. Bell, 181 U.S. 175 (1901). The use of domicile as the basis for jurisdiction in divorce cases has been criticized. See, e.g., Corwin, Out-Haddocking Haddock, 93 U. PA. L. Rev. 341, 356 (1945); Paulsen, Migratory Divorce: Chapters III and IV, 24 IND. L.J. 25, 36 (1948).

68 See Reese, Does Domicil Bear A Single Meaning?, 55 Colum. L. REv. 589 (1955). 60 Williams v. North Carolina, 317 U.S. 287, 322 (1942) (dissenting opinion). 60 Williams v. North Carolina, 325 U.S. 226, 258 (1945) (dissenting opinion).

${ }^{61}$ See Reese, supra note 58, at 590. Two courts using the same definition of domicile could, however, reach disparate results.
} 
ments in excess of their jurisdictions. In opposition to the attack are the constitutional command of full-faith-and-credit to judgments of sister states and the interests of the non-attacking party in the stability and certainty of his status. ${ }^{62}$

Where one of the parties attempts to challenge the validity of his out-of-state divorce, the Supreme Court has resolved this conflict by extending full-faith-and-credit to the out-of-state decree and barring either party who has entered a personal appearance from collaterally attacking it. ${ }^{63}$ Where a party did not appear either personally or by counsel, he may attack the foreign decree. ${ }^{64}$

Where a state challenges the validity of a foreign divorce decree in the course of a bigamy prosecution, the Supreme Court has not prescribed the situations in which collateral attack will be allowed. In the second Williams ${ }^{65}$ case it held that such a decree is not entitled to fullfaith-and-credit if, upon review of the first state's determination, it is found that there was no bona fide domicile. The problem, of course, is when to allow such review. In Williams the divorce proceedings had been entirely ex parte and the Court held that the state was not barred. This does not, however, solve the problem created by difficult cases hike Sherrer, ${ }^{66}$ where there is minimum participation by both parties. ${ }^{67}$ Assuming a remarriage by one of the parties to a Sherrer-type divorce, should that divorce be subject to attack in a bigamy prosecution brought by another state?

At first glance it might appear appropriate to apply the dictum in Durfee to the effect that a state is not bound by litigation to whicl it was not a party. ${ }^{68}$ Closer analysis, however, slows this dictum to be in-

${ }^{62}$ See Dainow, Policy Considerations in Divorce Jurisdiction and Recognition, 10 LA. L. REv. 54 (1949).

63 Sherrer v. Sherrer, 334 U.S. 343 (1948). Johnson v. Muelberger, 340 U.S. 581 (1951), interpreted the holding in Sherrer as barring not only those parties who appeared, but also those personally served.

04 Rice v. Rice, 336 U.S. 674 (1949). It has not been settled that appearance by counsel will estop the parties from collaterally attacking the decree, but since the opportunity to contest jurisdiction has been presented, this seems to be the result consistent with Sherrer.

65 Wilkams v. North Carolina, 325 U.S. 226 (1945).

68 Sherrer v. Sherrer, 334 U.S. 343 (1948).

07 In Johnson v. Muelberger, 340 U.S. 581 (1951), a case involving a Sherrer-type divorce, the Court used broad language which might be interpreted as an indication that it would bar a state from collaterally attacking the decree in such cases. Id. at 588. See EHREnzwetg, Conflict of Laws 253 (1962); Comment, 24 U. Cru. I. Rev. 376, 380 (1957). There is, however, no assurance that the Court had this situation in mind, and it is not at all certain that Johnson closes the question. See voN MEBREN, The Validity of Foreign Divorces, 45 Mass. L.Q. 23, 29 (1960).

$68 \mathrm{Mr}$. Justice Jackson apparently thought that a state would never be barred from attacking a decree to which it was not a party. "Davis v. Davis . . . in no way indicates that a finding of domicile after appearance of the absent spouse and litigation of the 
apposite. A subsequent action between the interested states in Durfee would involve no problem of full-faith-and-credit; Missouri could recognize the Nebraska judgnient and consistently bring an action to enforce its own interests. A bigamy prosecution, on the other hand, requires a refusal of full-faith-and-credit to the out-of-state divorce decree, since recognition of that decree would be decisive of the bigamy question. Thus we are again faced with the conflict between the constitutional command of full-faith-and-credit and the rule that a judgment rendered without jurisdiction is void and subject to collateral attack.

To resolve this conflict the interests of the attacking state must be examined. Unless they outweigh the constitutional policy of full-faithand-credit it appears that the state will be barred from attacking the validity of the out-of-state decree. ${ }^{69}$ Cases which lave barred an individual from challenging the out-of-state divorce are not decisive of the question because they fail to consider all the state's interests. In Sherrer, for example, although the interests of the state in the attempted attack on the Florida decree were dismissed as inferior to the constitutional policy of full-faith-and-credit, ${ }^{70}$ it is probable that they were given only secondary consideration. ${ }^{71}$ The Court emphasized the interests of the parties and barred the attacker on what is, in effect, an estoppel theorya theory which could not be used against the state because it had no opportunity to contest jurisdiction. Since the interests of the parties in this type of divorce are usually adverse to those of the attacking state, it is also doubtful that the state had effective representation in the original action. ${ }^{72}$ When parties confer jurisdiction on a state court in order to take advantage of its lenient attitude towards divorce, a genuine contest of the jurisdictional issue cannot be expected.

Moreover, a bigamy prosecution presupposes new state interests and provides a vehicle for the state to assert them. The power to define and punish immoral conduct by criminal sanction lies with the state and the state's interest in enforcing its criminal laws lias traditionally been strong. Having had no opportunity to assert its interests in the out-of-state proceedings, perliaps the state sliould be allowed to attack those proceedings when its criminal laws are violated by a subsequent

question would be conclusive upon the state of his domicile in litigation involving its interests and not merely those of the parties." Williams v. North Carolina, 317 U.S. 287, 320 n.7 (1942) (dissenting opinion).

69 See notes 11-24 supra and accompanying text.

70 It should be observed that the wife in Sherrer had subsequently remarried, creating a potential situation of bigamy. Perhaps this implies that even the state's interest in its bigamy laws will be insufficient to override the federal policy of full-faith-and-credit.

71 See Paulsen, supra note 57, at 34.

72 See von MEHREN, supra note 67 , at 29 
marriage. This rule need not apply to every divorce decree. Where the question of domicile was genuinely contested in another state, collateral attack should be denied; there is no reason to think that the attacking state's determination would be any more reliable. ${ }^{73}$ Where, however, there was no bona fide contest of the question of domicile in the out-of-state proceedings, it might be desirable to allow the prosecuting state to examine the first state's determination. ${ }^{74}$

The salutary effect of such a rule is apparent; it would provide the states with a defense against the scandalous "quickie" divorce. It should be recognized that although one might personally favor lenient divorce laws, our system reserves to each state the power to prescribe for its domiciliaries whatever standards it chooses. What is at stake is not the relative merits of a strict or lenient divorce policy, but rather the integrity of the legal process. ${ }^{75}$ Cases hike Sherrer might be defended on the grounds that, by facilitating divorce, they more closely conform to prevailing public attitudes; admittedly a number of states have strict divorce laws that renain in force largely due to inertia and the hesitancy of state legislatures to offend the groups which advocate them. ${ }^{76}$ These cases, however, have insidious effects. which must be recognized. They encourage collusion and fraud; the majority of "quickie" divorces are the product of perjury. ${ }^{77}$ And by providing an easy means for circumventing a strict state policy they renove pressure from the legislatures to revise outmoded laws. ${ }^{78}$ The net effect is to subvert state divorce pohicies via extralegal routes, and to reduce inevitably public respect for the legal process.

The apparent drawback to such a rule is that it would leave parties to a divorce uncertain of their status. Theoretically there would be nothing to prevent a state from prosecuting for bigamy whenever a marriage is preceded by an out-of-state divorce in which the question of ${ }_{g}$ jurisdiction was not contested. ${ }^{79}$ In practice, lowever, the states would probably prosecute in only the most flagrant cases. ${ }^{80}$ The real

73 Id. at 29-30.

74 Id. at 29. Contra, EERENzWEIG, Conflict of Laws 253 (1962); Swanson, Migratory Divorce: The Sherrer Case and the Future-A Prophecy, 40 A.B.A.J. 672, 675 (1954).

75 See Paulsen, supra note 57, at 41.

76 See 61 Yaxe L.J. 238, 244 (1952).

77 See Paulsen, supra note 57 , at 41 .

78 See von MEHREN, supra note 67 , at 35 .

79 Justice Black expressed grave concern over this problem in his dissent in the second Williams case. Williams v. North Carolina, 325 U.S. 226 (1945). Subsequent events have proved his fears unjustified. See discussion note 80 infra.

80 Foster, For Better or Worse? Decisions Since Haddock v. Haddock, 47 A.B.A.J. 963, 965 (1961). In checking the 800-1000 cases listed in Shepard's Citations as citing Williams II, a student researcher for Professor Foster uncovered only one criminal 
danger would lie in arbitrary prosecution. Perhaps arbitrariness would be desirable, since the fear it would engender would put a damper on the six week vacation in a Nevada motel, with the consequent divorce and remarriage.

There are better ways to solve the problem of the "quickie" divorce; it has been suggested that residence for a definite period of time, e.g., one year, be substituted for domicile as the basis for jurisdiction. ${ }^{81}$ This would impart stability and certainty into the area of divorce recognition, but so long as domicile is retained as the jurisdictional basis for divorce, another solution must be found. The facilitation of bigamy prosecutions is not the ideal solution and is certainly not suggested as a panacea. It would, lowever, strengthen the power of the individual states to apply their policies of divorce to their own domiciliaries.

\section{The Aftermath of a Bigamy Prosecution}

The concurring opinion suggests another problem. Assuming a successful bigamy prosecution after a Sherrer-type divorce, what would be the status of the parties in the state which rendered the original decree? Althougl this situation comes closest to that posed by Justice Black's caveat in Durfee, the analogy is imperfect. No collateral attack is involved in a subsequent action between Missouri and Nebraska to determine ownership of the land. A bigamy conviction, lowever, necessitates a finding that the out-of-state divorce was invalid. Having been collaterally attacked and slown to be void, the decree would seem to be void everywhere--even in the rendering state. ${ }^{82}$

The Supreme Court, however, has never passed on this question, and there were intimations in the Williams cases that the divorce could be void in North Carolina while remaining valid in Nevada. ${ }^{83}$ Sucl a conclusion must be based on the premise that Nevada can, without a denial of due process, render a divorce decree on any jurisdictional grounds it chooses that will be valid within its boundaries. The premise seems unsound. A decree by Nevada divorcing parties not actually domiciled within the state affects the res of the marriage which is outside its jurisdiction. It alters a relationship over which it has no jurisdiction and encroaches upon the domain of a sister state. If domicile is to be

prosecution comparable to Williams. Id. at $965 \mathrm{n} .28$. Thus the present discussion appears to be mainly of academic value.

81 See Paulsen, supra note 57. This could be accomplished either by an Act of Congress or by Supreme Court decision.

82 See McDonough, Mr. Justice Jackson and Full Faith and Credit to Divorce Decrees: A Critique, 56 CormM. L. Rev. 861, 863 (1956).

83 Williams v. North Carolina, 317 U.S. 287, 319 (1942) (dissenting opinion); Williams v. North Carolina, 325 U.S. 226, 238 (1945); id. at 239 (concurring opinion). 
the basis for jurisdiction in a divorce suit, then the finding by the North Carolina court that no bona fide domicile existed in Nevada should deprive the Nevada decree of any validity wlatsoever. ${ }^{84}$ The only avenue open to the convicted parties is that of direct appeal..$^{85}$ The other view leaves the parties legally married in Nevada and criminals in North Carohina-an anomalous situation.

Victor J. Haydel, Jr.

84 Cf. Treinies v. Sunshine Mining Co., 308 U.S. 66 (1939). See also 24 U. CHr. L. REv. 376, $385 \& \mathbf{n} .64$ (1957).

85 Treinies v. Sunshine Mining Co., supra note 84. 